\title{
PENGARUH PELAYANAN JASA ANTAR JEMPUT UANG TABUNGAN TERHADAP LOYALITAS NASABAH PT.BPRS SAFIR BENGKULU CABANG CURUP
}

\author{
NIA NATALIA \\ Politeknik Raflesia, Kabupaten Curup, Bengkulu
}

\begin{abstract}
Abstraksi: Dalam dunia Perbankan pelayanan tentulah salah satu fasilitas yang diutamakan oleh banyak nasabah, pelayanan sangat bergunabagi nasabah yang mengalami kesulitan tentunya. Salah satunya adalah para pedagang pasar atas Curup yang tidak bisa selalu meninggalkan barang dagangannya untuk sekedar bertransaksi ke perbankan, dikarenakan para pedagang biasanya menghabiskan waktu mereka ditempat mereka melakukan kegiatan usaha. Oleh karena itu penulis tertarik untuk mengetahui apakah ada pengaruh pelayanan jasa antar jemput uang tabungan kepada pedagang pasar atas curup terhadap loyalitas nasabah. Jenis penelitian ini adalah penelitian lapangan dengan pendekatan kuantitatif. Populasi yang diambil dalam penelitian ini adalah nasabah PT.BPRS SAFIR Bengkulu Cabang Curup yang berprofesi sebagai pedagang Pasar Atas Curup sebanyak 200 responden. Menggunakan teknik Simple Random Sampling yang diambil secara acak sebesar 15\% dari jumlah populasi 200 responden yang menggunakan pelayanan jasa antar jemput uang tabunganya itu 30 responden. Data dikumpulkan dengan penyebaran angket yang disebarkan kepada pedagang pasar atas Curup. Data yang terkumpul dianalisis menggunakan teknik analisis regresi sederhana dan SPSS16.0. Dari hasil analisis angket mengenai pengaruh pelayananjasa antar jemput uang tabungan kepada pedagang pasar atas Curup terhadap loyalitas bahwa $R$ square $\left(R^{2}\right)$ adalah 0,491 yang bila ditulis dalam bentuk persentase 49,1\%. Angka tersebut menjelaskan bahwa determinasi atau sumbangan pengaruh variable pelayanan jasa antar jemput uang tabungan terhadap loyalitas adalah sebesar 49,1\%. Jadi hipotesis Ha diterima dan hipotesis Ho ditolak.
\end{abstract}

Kata kunci: Pelayanan, PT. BPRS SAFIR Bengkulu Cabang Curup, Pedagang, Loyalitas Nasabah 


\section{PENDAHULUAN}

Penilaian masyarakat terhadap lembaga keuangan dipengaruhi oleh bagaimana masyarakat tersebut memaknai produk bank atau pelayanan jasa yang diterima ketika masyarakat bertemu langsung dengan pihak lembaga keuangan. Kegiatan usaha lembaga keuangan baik di dunia perbankan maupun bukan perbankan yaitu dapat berupa menghimpunan dana dari masyarakat atau dengan kata lain melakukan simpanan tabungan dan menyalurkan dana kembali kepada masyarakat atau kredit bagi konvensional dan pembiayaan bagi perbankan syariah, baik itu untuk melakukan kegiatan individu maupun organisasi.

Pedagang biasanya menghabiskan waktu di tempat mereka melakukan kegiatan usaha, sebagian besar bahkan tidak mempunyai waktu untuk melakukan aktifitas perbankan. Maka dari itu lembaga keuangan baik perbankan maupun koperasi memberikan pelayanan-pelayanan yang dapat diterima baik oleh kalangan pedagang. Akan tetapi khusus pada pedagang PT.Bank Pembiayaan Rakyat Syariah (BPRS)SAFIR Bengkulu Cabang Curup menyediakan pelayanan jasa antar jemput uang tabungan bagi para pedagang yang memudahkan para pedagang untuk tetap menabung walaupun mereka menjalankan aktivitas usahanya tanpa terkendala.

Dari hasil wawancara dengan karyawan PT. Bank Pembiayaan Rakyat Syariah (BPRS) SAFIR Bengkulu Cabang Curup mengatakan bahwa ada sekitar 200 orang nasabah yang berprofesi sebagai pedagang Pasar Atas Curup yang menggunakan pelayanan jasa antar jemput uang tabungan. Permasalahanya apakah dengan tersedianya pelayanan jasa yang menguntungkan ini semakin membuat para pedagang tetap loyal dalam melakukan kegiatan menabung di perbankan syariah khususnya Bank SAFIR.

Untuk menghindari meluasnya masalah yang akan diteliti dan terarahnya penelitian ini, maka penulis mengangkat permasalahan hanya pada masalah pengaruh pelayanan jasa antar jemput uang tabungan kepada pedagang pasar atas Curup terhadap loyalitas nasabah.

\section{METODE PENELITIAN}

\section{DesainPenelitian}

Jenis penelitian yang digunakan dalam penelitian ini merupakan penelitian lapangan (FieldResearch) dengan pendekatan kuantitatif, karena hasil penelitian berupa data-data akan dikonversikan dalam bentuk angka-angka yang kemudian dihitung dan dianalisis dengan teknik statistik. Dalam penelitian ini variable bebas $(X)$ adalah Pelayanan jasa antar jemput uang 
tabungan dan Variable (Y) adalah loyalitas nasabah. Penelitian ini dilakukan di PT. BPRS SAFIR Bengkulu Cabang Curup. Perusahaan tersebut berlokasi di Jl. Sukowati No. 69A Curup Rejang Lebong Telp/Fax.(0732)22636. Waktu penelitian dilakukan selama kurang lebih dua bulan, yaitu pada bulan Maret sampai April tahun 2017.

\section{Definisi Operasional Variabel Penelitian}

Adapun Variabel penelitiannya yaitu:

a. Variabel Bebas

Variabel bebas adalah suatu variabel yang mempengaruhi variabel lain. Variabel bebas dalam penelitian ini adalah Pelayanan Jasa Antar Jemput Uang Tabungan.

b. Variabel Terikat

Variabel terikat adalah variabel yang dipengaruhi atau yang diukur untuk mengetahui besarnya variabel lain. Variabel terikat dari penelitian iniadalah loyalitas nasabah.

\section{a. Populasi}

\section{POPULASI DANSAMPEL PENELITIAN}

Yang digunakan sebagai objek penelitian adalah para pedagang pasar atas Curup yang menggunakan pelayanan jasa antar jemput uang tabungan yang berjumlah200 orang.

\section{b. Sampel}

Dalam penelitian ini, peneliti mengambil sampel sebanyak 15\% dari jumlah populasi. Untuk lebih jelasnya dapat dihitung dengan cara berikut:

$$
\begin{aligned}
& \mathrm{n}=\mathrm{N} \times 15 \% \\
& \mathrm{n}=200 \times 15 \%=30 \text { orang }
\end{aligned}
$$

Uraian diatas tersebut diambil dari pendapat Suharsimi Arikunto, apabila subjek kurang dari 100, lebih baik diambil keseluruhan sehingga penelitian populasi selanjutnya. Selanjutnya jika populasi lebih dari 100 maka diambil $10-15 \%$ atau $20-25 \%$ atau lebih, tergantung setidak-tidaknya dari kemampuan peneliti.

Teknik penarikan sampel yang digunakan dalam penelitian ini adalah pengambilan sampel secara acak atau random sederhana (Simple Random Sampling). Menurut Iskandar(2010:70)Pengambilan sampel secara acak atau random dari populasi, memungkinkan setiap individu berpeluang untuk menjadi sampel penelitian, dengan cara rendomisasi atau dengan cara melalui undian. Penyampelan ini dilakukan karena populasi dianggap seragam (homogen).

\section{Instrumentasi danTeknik Pengumpulan data}

\section{a. Intrumentasi}

1) Data Primer 
Untuk penelitian ini data diperoleh dengan cara penyebaranangket (Quesioner).Dalamhalinipenulis akan melakukan penyebaran kuesionerkepadaPedagangPasar AtasCurup.

2) Data Sekunder

Data sekunder ini diperoleh berdasarkan sumber lain yang berhubungan dengan penelitian ini yaitu dari Dosen, masyarakat, jurnal, dan bukubuku yang berhubungan dengan penelitian maupun dari sumber lainnya.

\section{b. Teknik Pengumpulan Data}

Berbagaimetodeyangdikumpulkandalampenelitianinidilakukandengan berbagaicara, antar lainmenggunakan teknik:

a.Observasi

Menurut Masri Singarimbun dan Sofian Efendi (2010) Observasi merupakan suatu penyelidikan yang dijalankan secara sistematik dengan sengaja dengan menggunakan alat indera terhadap kejadian-kejadian yang langsungditangkappadawaktu kejadiannya.

b.Kuesioner

Menurut Sugiyono (2011:135) Kuesioner merupakan teknik pengumpulan data yang dilakukan dengan cara memberikan seperangkat pertanyaanatau pertanyaan tertulis kepada responden untuk di jawab||. Kuesioner atau angket yang digunakan pada penelitian ini menggunakan jenis angket tertutup yang terdiri dari sejumlah pertanyaan dan jawaban yang harus dipilih oleh responden. Angket yang disusun untuk memperoleh data penelitian variabel X(Pelayanan Jasa Antar JemputUang Tabungan),variabel Y (Loyalitas Nasabah).

\section{c.Dokumentasi}

Dokumentasi adalah data yang berupa dokumen yang diperlukan dalam penelitian iniuntukmengetahuipengaruh pelayananjasa antar jemputuang tabungan kepada pedagang pasar atas Curup, serta kondisi objektif wilayah penelitian yakni Profil Pasar Atas Curup.

\section{d.Kepustakaan}

Teknik ini digunakan untuk mendapat datayang berkenaan dengan teori yangsesuai dengan penelitian penulis.

\section{TeknikAnalisisData}

Teknik Analisis data yang digunakan dalam penelitian ini adalah metode analisa kuantitatif dimana dalam menganalisis penelitian ini menggunakan analisis regresi sederhana (Simple Regression). Dalam penelitian ini untuk mengetahui ada tidaknya pengaruh pelayanan jasa antar jemput uang tabungan kepada pedagang pasar atas terhadap loyalitas dan seberapa signifikan pengaruhnya. Bisa menggunakan Uji Validitas dan reabilitas. 


\section{a.Uji Validitas}

Uji Validitas digunakan untuk mengukur sahat atau tidaknya suatu kuesioner. Pertanyaan dinyatakan valid jika mempunyai $r$ hitung yang lebih besar dari $r$ tabel yaitu $>0,361$, sehingga item kuesioner valid dan dapat dijadikan acuan untuk penelitian selanjutnya.

\section{b.Uji Reliabilitas}

Dalam penelitian ini juga, pengolahan data statistic selain dihitung secara manual juga dihitung dengan menggunakan program computer yaitu SPSS 16.0 agar semakin kuat kebenarannya. SPSS (Statistical Package for the Social Sciences) adalah salah satu program aplikasi statistic yang paling banyak dipakai oleh pengguna komputer. Program ini memiliki kemampuan analisis statistik cukup tinggi, memiliki interface pada lingkungan grafis dengan cara pengoperasian yang cukup sederhana sehingga mudah untuk dipahami pamakaiannya. Metode yang digunakan dalam penelitian ini dimulai dengan gambaran per indikator.

1.Mencari Mean

$\mathrm{M}=\frac{\Sigma \mathrm{fx}}{\mathrm{N}}$

$\mathrm{M}$ = Meanyangdicari

$\Sigma \mathrm{fx}=$ Jumlah dari hasilperkalian antara mid point dari masing interval dengan frekuensi

$\mathrm{N}$ = Number of cases (banyaknya subjek yang diteliti).

\section{Mencari Standar Deviasi}

$\mathrm{SD}=\frac{\sqrt{\Sigma \mathrm{fx}^{2}}}{\mathrm{~N}}$

$\mathrm{SD}=$ Standar Deviasi

$\Sigma \mathrm{fx}=$ Jumlah hasilperkalian antarafrekuensi masing-masinginterval

$\mathrm{N}$ =Number of cases (banyaknya subjek yang diteliti).

Berdasarkan perhitungan standar deviasi ini maka dapat disusun kriteria minat Menabung adalah sebagai berikut:

$$
\begin{array}{ll}
\mathrm{M}+1 . \mathrm{SD} & =\text { Sangat Berpengaruh } \\
\mathrm{M}+0,5 . \mathrm{SD} & =\text { Berpengaruh } \\
\mathrm{M}-0 . \mathrm{SD} & =\text { Cukup Berpengaruh } \\
\mathrm{M}-0,5 . \mathrm{SD} & =\text { Tidak Berpengaruh } \\
\mathrm{M}-1 . \mathrm{SD} & =\text { Tidak Berpengaruh Alat }
\end{array}
$$

Analis Datayangdigunakan:

\section{1) Regresi LinearSederhana}

Hasan (2010:219) Untuk dua variabel, hubungan liniernya dapat dinyatakan dalam bentuk persamaan linier,yaitu:

$\mathrm{Y}=\mathrm{a}+\mathrm{bX}$ 
Dimana:

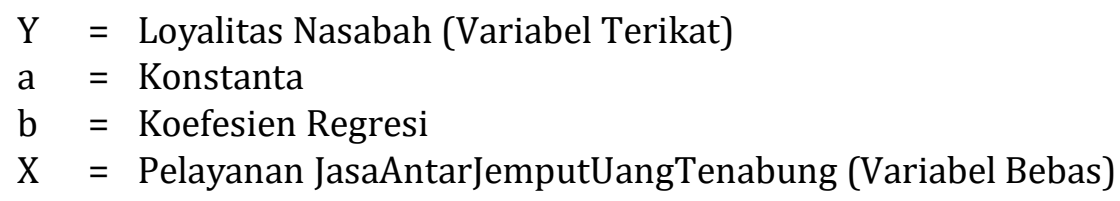

\section{2) Uji t}

Dalam penelitian inimenggunakan duaVariabelyaitu pengaruh pelayanan tabungansebagaivariabelXdanminatnasabahbaruuntuk menabungsebagaiVariabelY.Data-datadaninformasi yangtelahterkumpul kemudiandianalisisdanditelitimelaluiuraianyang dapatmenyatakandan menggambarkan hasil penelitian yang dilakukan sesuai dengan permasalahan yang diangkatyakniPengaruhPelayananJasaAntar JemputUang TabunganKepada PedagangPasarAtasCurup TerhadapLoyalitas Nasabah.

Untukmempermudahdalampemecahanmasalahmaka peneliti menggunakananalisiskuantitatifyangmenggunakanstatistikdalammengolah danmenganalisisdata, dimanaberdasarkannilaijawabanyang diberikankepada responden,maka dibuatkriteria untukmempermudah mencarikriteriajawaban responden tentang Pengaruh Pelayanan Jasa Antar Jemput Uang Tabungan KepadaPedagangPasarAtasCurup TerhadapLoyalitas Nasabah.

\section{3) KoefisienDeterminasi ( $R^{2}$ atauR-square)}

Purwanto(2011:192-194)Langkahterakhirnyaadalah menentukan koefisien determinasi.Indeks determinasidiberi notasidengan $\mathrm{R}^{2}$.Indeks determinasi menunjukanbesarnya sumbanganvariablebebas(X)kedalamvariableterikat.

\section{HASIL ANALISIS DATA DAN PEMBAHASAN}

\section{Pelayanan Jasa Antar Jemput Uang Tabungan Kepada Pedagang Pasar Atas Curup pada BPRS SAFIR Bengkulu CabangCurup}

Untuk mengetahuipelayananyang telah diberikanBPRSSAFIRBengkulu CabangCurupkepadapedagang pasaratasCurupdapatdilihatdari beberapa indikator diantaranya:

\section{Fasilitas}

Dalamperbankan,sistempelayananharus didampingidenganfasilitasyang menunjang agarnasabahmerasakanpelayananyang membuatmereka nyaman. Fasilitasyang disediakanBPRSSAFIRmemang belummemadaisepertibankbanklainyang mempunyaifasilitasATM,akantetapiBPRSSAFIRmempunyai fasilitasyang lainnyasepertipelayananjasaantarjemputuang tabungankepada 
pedagang pasar atas ini, yang menunjang pelayanan tetap optimal. Untuk mengetahuigambaranfasilitaspelayananjasaantarjemputuang tabunganmaka dari dataangketdibuatdalamtabeldistribusifrekuensi

Dari tabel kategori fasilitas 4 responden(13,3\%)menyatakan sangat setuju dan9responden(30\%)setujudan3responden(10\%)menyatakanraguragu,dan 5 responden $(16,7 \%)$ menyatakan tidak setuju serta 9 responden (30\%) menyatakan sangat tidak setuju. Kalau dikategorikan menjadi dua. Pertama, sangatsetuju,setujudanraguraguterdapat16responden(53,3\%) setujujika fasilitasyang diberikanBPRSSAFIRmenunjang pelayananyang diberikanoleh parapedagang pasaratasCurup.Kedua,tidaksetujudansangat tidak setuju14 responden $(46,7 \%)$ tidak setuju atau sangattidak setuju dengan indikator fasilitas. Sehinggadapat disimpulkan bahwasebagian para pedagangsetuju.

\section{Rasa Aman}

Untukmengetahuigambaran rasa aman,maka daridataangketdibuatdalam bentuk tabel Distribusi Frekuensi.

Dari tabel kategori rasa aman, 12 responden (40\%) menyatakan sangat setujudan8responden(26,67\%) menyatakanraguragu,serta10responden menyatakansangattidaksetuju.Kalaudikategorikanmenjadidua.

Pertama,sangatsetuju,setujudan ragu-raguterdapat20responden(66,67\%) setuju jika rasa aman yang diberikan BPRS SAFIR membuat para pedagang merasa nyamandan aman.Kedua,tidaksetujudansangattidaksetuju10 responden(33,33\%) tidaksetujuatausangattidaksetujudenganindikatorrasa amanyang diberikanolehBPRSSAFIRBengkuluCabangCurup.Sehinggadapat disimpulkanbahwaparapedagang mempunyairasaamanakarena66,67\% pedagangsetujuterhadaprasa amanyangdiberikan BPRSSAFIR.

\section{Karyawan}

Untukmengetahuigambaranpelayanandarisudutpelayananyang diberikan olehkaryawanBPRSSAFIRketikamelayanipara pedagang pasaratasCurup, makadari dataangket dibuat dalam bentuk tabelDistribusi Frekuensi.

Daritabelkategorikaryawan,7 responden(23,33\%) menyatakansangat setuju dan 13 responden $(43,33 \%)$ menyatakan setuju, serta 10 responden $(33,34 \%)$ menyatakantidaksetuju.Kalaudikategorikanmenjadidua.Pertama, sangatsetuju,setujudanragu-raguterdapat20responden(66,66\%) setujujika karyawanBPRSSAFIRmelayanipara pedagangdenganbaikdansesuaidengan keinginanpedagang tanpapilihkasihdanramahjikamelayani mereka.Kedua, tidaksetujudansangat tidaksetuju10responden(33,34\%)tidaksetujuatau sangattidaksetujudenganindikatorkaryawanBPRSSAFIRBengkuluCabang Curup.Sehingggadapatdisimpulkan66,67\%pedagangsetujuterhadapkaryawan BPRS SAFIRketikamelayani merekauntuk antarjemput uangtabungan. 


\section{Loyalitas Para Pedagang Pasar Atas Curup terhadap BPRS SAFIR Bengkulu Cabang Curup}

Dalam penelitian ini, dapat dihimpun data dari sampel yang diambil, diketahui sebanyak 30 orang nasabah BPRS SAFIR yang menggunakan Pelayanan Jasa Antar Jemput Uang Tabungan khususnya pedagang pasaratas Curup. Untuk mengetahui factor apa saja yang mempengaruhi loyalitas, maka dibuat dalam bentuk Distribusi Frekuensi perindikator sebagai berikut:

\section{Loyal}

Untuk gambaran loyalitas nasabah dari indicator Setia, maka dari angket dibuat dalam bentuk tabel Distribusi Frekuensi.

Dari table kategori setia 10 responden $(33,33 \%)$ menyatakan sangat setuju dan 10 responden $(33,33 \%)$ setuju serta 1 responden $(3,34 \%)$ menyatakan ragu-ragu dan 4 responden (13,33\%) menyatakan tidak setuju serta 5 responden $(16,67 \%)$ menyatakan sangat tidak setuju. Kalau dikategorikan menjadi dua. Pertama, sangat setuju, setuju dan ragu-ragu terdapat 21 responden (70\%). Kedua, tidak setuju dan sangat tidak setuju 9 responden $(30 \%)$ tidak setuju atau sangat tidak setuju. Disini bisa penulis simpulkan bahwa sebagian besar para pedagang pasar atas Curup setuju dengan indikator setia.

\section{Mempromosikan}

Untuk gambaran indicator mempromosikan ada dalam pertanyaan nomor 29 dan 30, maka dari data angket dibuat dalambentuk tabel Distribusi Frekuensi. Dari table kategori mempromosikan 19 responden (63,33\%) menyatakan setujudan3responden (10\%) ragu-ragudan8responden(26,67\%)menyatakan tidak setuju. Kalau dikategorikan menjadidua.Pertama, sangatsetuju, setuju dan ragu-ragu terdapat22 responden (73,33\%).Kedua, tidak setuju dan sangattidak setuju 8 responden(26,67\%). Disini bisadisimpulkan bahwaparapedagangsetuju untuk mempromosikan kembali kepada keluarga dan masyarakat tentang pelayanan jasa antar jemput uangtabunganyang merekagunakan.

\section{Lama Menabung}

Untukmemahamigambaranloyalitas nasabahuntukindikator lama menabung,maka daridataangketdibuatdalam bentuktabelDistribusiFrekuensi Berdasarkan tabeldapatdiketahuibahwadari 30 responden, jumlah sampel terbanyak adalah responden yang sudah 3 bulan menabung di BPRS SAFIRBengkulu CabangCurup sebesar 16,7\%atau 5 orangresponden.

\section{Pengaruh Pelayanan Jasa Antar Jemput Uang Tabungan Kepada PedagangPasarAtasCurupTerhadapLoyalitas Nasabah}

Untuk mengetahui seberapa besar pengaruh pelayanan jasa antar jemput uang tabungan kepada pedaagang pasar atas Curup terhadap loyalitas nasabah, maka perlu dilakukanan alias dengan metode perhitungan. Adapun metode perhitungan tersebut, penulis memaparkan metode yakni sebagai 
berikut:

\section{Uji Validitas danReabilitas Kuesioner}

Dari data hasil uji validitas variabel pelayanan jasa antar jemput uang tabungan kepada pedagang pasar atas Curup (X) tersebut dapat disimpulkan bahwa 1 item pertanyaan dinyatakan tidak valid karena nilainya kurang dari 0,361 .

Nilai koefisien diatas adalah 0,929 . Sesuai dengan koefisien, nilai ini sudah lebih besar dari 0,60, maka hasil data angket variabel $\mathrm{X}$ memiliki tingkat reabilitas yang baik atau dengan kata lain data angket dapat dipercaya.

Nilai koefisien diatas adalah 0,929. Sesuai dengan koefisien, nilai ini sudah lebih besar dari 0,60, maka hasil data angket variabel $\mathrm{X}$ memiliki tingkat reliabilitas yang baik atau dengan kata lain data angket dapat dipercaya.

Sehingga dapat disimpulkan dengan teknik analisis yang digunakan sebagai berikut :

\section{Analisis Regresi LinearSederhana}

Analisisinidigunakanuntukmengetahuipengaruh pelayananjasaantar jemputuang tabungankepadapedagang pasaratasCurupterhadaployalitas nasabah.Berdasarkan hasil perhitungan, didapatkan hasil sebagai berikut :

a. Nilai Konstanta (a) sebesar 38,381, karenanilaiadalamgaris regresi bertanda positif(+)denganangka38,381,makagarisregresiakanmemotong sumbuY diatas origin (0) pada angka38,381.

b. NilaiKoefisienregresi variabelpelayanansebesar0,446menunjukanarti bahwavariabelXtersebuttergolong inelastic,karenanilaib $<1$.Artinya, setiap perubahan nilai Xakan diikutiperubahanyanglebih kecil padanilai Y. Tandapositifpadaparameterbtersebutmenunjukanbahwa jikavariabelX meningkatmaka Y juga akanmeningkat. Sebaliknya,jika X mengalami perubahanyangmenurun,makaYjugaakanmenurun denganperbandingan perubahan 1:0,446.

\section{Nilai t Hitung}

Nilaithitung adalahpengujiansignifikanpengujiansignifikanuntuk mengetahui pengaruhvariabelX terhadap variabelY, apakah berpengaruh signifikanatautidak.Untukmengetahuihasilnya signifikanatautidak,angka $\mathrm{t}$ hitungakan dibandingkandengan $\mathrm{t}$ tabel.

a. Merumuskan hipotesis

Ho =Tidakadapengaruhsignifikanantara pelayananjasaantarjemputuang tabungan kepadapedagangpasar atasCurupterhadap loyalitas.

b. Menentukan t hitungdansignifikan

Dari outputdidapat thitungsebesar 5,194 dan signifikansi sebesar 0,000

c. Menentukan t tabel

$\mathrm{T}$ tabeldapatdilihatpada tabelstatistiksignifikansi0,05/2=0,025dengan derajatkebebasandf $=\mathrm{N}-2=30-2=28$. Hasilyangdilihatdarittabel adalah sebesar 2,048. 
d. Kriteriapengujian

1) Jika t hitung $>$ t tabel, makaHo ditolak

2) Jika t hitung $<$ t tabel, makaHo diterima

Berdasarkan signifikansi:

1) Jika Signifikansi $>0,05$. MakaHo diterima

2) Jika Signifikansi < 0,05. MakaHo diterima

e. Membuat kesimpulan

Karenanilaithitung >darittabel(5,194>2,048)dansignifikansi $>0,05$ $(5,194>0,05)$, makaHa diterima dan Hoditolak.Artinyaadapengaruhyang signifikanantara variabelX(Pelayananjasaantarjemputuang tabungan)terhadapvariabelY (Loyalitas Nasabah).

\section{KoefisienDeterminasi ( $\mathbf{R}^{2}$ atau $\mathbf{R}$-square)}

Koefisien determinasi $\mathrm{R}^{2}$ digunakan untukmelihatseberapabesar pengaruh variabelX (Pelayananjasantar jemputuangtabungan) terhadapvariabelY (Loyalitasnasabah).

Dari hasilperhitungan, dapat ditarik kesimpulan sebagai berikut:

a. BesarhubunganantaravariabelXdenganvariabelYyangdihitungdengan koefisienkorelasiadalah0,701.Halinimenunjukanrelevansiyangsangat erat(karenamendekati1daripada0)antarPelayananJasaAntarJemput Uang TabunganKepadaPedagang PasarAtasCurup(X)denganloyalitas Nasabah(Y).Arahhubunganyang positif(tidakadatandanegativepada angka0,0701menunjukansemakinbesar Pelayanan JasaAntarJemput Uang Tabungan Kepada Pedagang PasarAtasCurup akan mempengaruhiLoyalitas Nasabah.Demikian pulasebaliknya.

b. AngkaRsquare $\left(\mathrm{R}^{2}\right)$ adalah0,491yangbiladitulisdalambentukpersentase samadengan49,1\%.Angkatersebutmenjelaskanbahwa determinasiatau sumbanganvariabel PelayananJasa Antar JemputUangTabunganKepada Pedagang PasarAtasCurupterhadapLoyalitasNasabahadalah49,1\%. Artinya,sumbanganvariabellain(PelayananJasalainnyasepertitabungan warungdantoko,tabunganqurban,tabunganpelajardanprodukpembiayaan lainnya) terhadapLoyalitas Nasabah sebesar 50,9\%.

Dariperhitungandiatasdidapatbahwa PelayananJasa Antar JemputUang Tabungan Kepada Pedagang Pasar Atas Curup terhadap Loyalitas Nasabah sebesar49,1\%sedangkan50,9\%dari faktorpelayananjasa lainnya,seperti tabunganwarung dantoko,tabunganqurban,tabunganpelajardanproduk pembiayaan lainnya.

\section{Kesimpulan}

\section{KESIMPULAN DAN SARAN}

Dari hasil penelitian di atas dapat disimpulkan bahwa dari berbagai indikatorpelayananjasayang diterimaolehparapedagang pasaratasCurupyang meliputifasilitas,rasaamandankaryawansecara keseluruhanhasilnyaadalah setujudenganadanyapelayananjasaantarjemputuang tabungan.Dariberbagai 
indikatorloyalitasnasabahsecarakeseluruhanhasilnya adalah sebagian pedagang pasar atas Curuployal diPT. BPRSSAFIRBengkulu CabangCurup.

Hasilkorelasikeduavariabel,pelayananjasaterhadapparapedagang pasar atas Curup memiliki hubungan yang cukup erat. Sedangkan hasil regresi mengenaipelayananjasaantarjemputuang tabungankepadapedagang pasaratas Curupterhadaployalitasnasabahadalahsignifikan.Darihasilanalisa angket mengenaipengaruh pelayananjasa antar jemputuangtabungankepada pedagang

pasaratasCurupterhadaployalitasbahwaRsquare $\left(\mathrm{R}^{2}\right)$ adalah0,491yang bila ditulis dalam bentuk persentase49,1 \%. Angkettersebutmenjelaskan bahwadeterminasiatau sumbangan pengaruh variabelpelayananjasaantarjemputuangtabungan terhadaployalitasadalah sebesar $49,1 \%$.

\section{Saran}

1. BagiBPRS SAFIRBengkulu CabangCurupsecaraumum

Karenanasabahmerupakansalahsatuinti berlangsungnyaprosesusahadan merupakansumberdayamanusiayang

sangatberpengaruhterhadaporganisasi, maka nasabahharusdiperhatikandenganbaik,tentunyadenganmemberikan pelayanan yangberkualitaskepadanasabah,baikberupasikap,kemudahan dalam melakukan transaksi dan memperoleh informasi sehingga nasabah merasanyaman menabungdiBPRS SAFIRBengkulu CabangCurup.

2. Kepadamahasiswasemogapenelitian inidapatmenambah referensi dan bisa dijadikan acuan untuk penelitian-penelitian selanjutnya.

\section{DAFTAR PUSTAKA}

A.Karim, Adiwarman,Bank Islam AnalisisFiqih dan Keuangan, Jakarta: PT Raja Grafindo Persada, 2010

Harini, Sri Turmidi,Metode StatistikPendekatanTeoritis danaplikatif, Malang: UIN MalangPresss, 2008

Kasmis, Pemasaran Bank, Jakarta: Penerbit Kencana, 2011

Kotler, Philip, dan KevinLaneKeller,ManajemenPemasaran jilid I, ed. 12, Jakarta: PT.Indeks, 2010

Malayu S.PHasibuan,Dasar-Dasar Perbankan,Bandung:BumiAksara,2010

Noor, Juliansyah,MetodologiPenelitian: Skripsi,Tesis, Disertai, dan Karya Ilmiah, Jakarta: Kencana PrenadaMediaGroup, 2011

Poerwardaminta W.J.S, Kamus UmumBahasa Indonesia, Jakarta: Balai Pustaka. 2011

Rivai, Veithzal et al,Bankand Financial Institusion Management Conventional\& Sharia System, Jakarta: PT Raja Grafindo 
Persada2010

Singarimbun, Masridansofian Efendi, Metode Penelitian Survey, Jakarta:LPJ ES, 2010

Singgih Santoso,SPSS:MengolahData Secara Profesionalversi7.5. Jakarta:

PT ElexMedia Komputindo,2011

Sugiyono,Metode Penelitian Bisnis, Banding: CVAlfabeta, 2011

Sukardi, Metodologi Penelitian Pendidikan, Jakarta: BumiAksara, 2013

Supomo Bdan NIndrianto,Metode Penelian Bisnis Untuk Akuntansi dan Manajemen, Yogyakarta: BPFE,2012

Wawancaradengan pegawai PT. BPRSSAFIRBengkulu CabangCurup,6 Maret 2017. 